\title{
ECOLOGY
}

\section{THE CLIMATE CHANGE IMPACT ON THE GLACIERS OF GEORGIA}

\author{
${ }^{I}$ Dr. G. I. Kordzakhia, ${ }^{1}$ Dr. L. D. Shengelia, ${ }^{2}$ Dr. G. A. Tvauri, ${ }^{3}$ Mr. M. Sh. Dzadzamia \\ ${ }^{I}$ Georgian Technical University, Institute of Hydrometeorology; \\ ${ }^{2}$ Iv. Javakhishvili Tbilisi State University, Nodia Institute of Geophysics; \\ ${ }^{3}$ National Environmental Agency, Department of Hydrometeorology, \\ Georgia, Tbilisi
}

\section{DOI: https://doi.org/10.31435/rsglobal_ws/30042019/6467}

\begin{abstract}
ARTICLE INFO
Received: 27 February 2019

Accepted: 08 April 2019

Published: 30 April 2019

KEYWORDS

climate change;

glaciers;

satellite remote sensing,

melting.

ABSTRACT

The article reviews the changes of the glacier basins characteristics of Georgia glaciers due to the current climate change. Calculations show significant decrease of the area and number of the glaciers in Georgia over the last 50 years. This reduction is more intensive in eastern Georgia in comparison with the western part of the country. At the same time, some large glaciers complete melting dates are determined according to one of the basic scenarios of current climate change, namely the business as usual. Based on the calculations it is concluded that viewed large glaciers complete melting is not expected within this century even in this worst conditions scenario.
\end{abstract}

Citation: G. I. Kordzakhia, L. D. Shengelia, G. A. Tvauri, M. Sh. Dzadzamia. (2019) The Climate Change Impact on the Glaciers of Georgia. World Science. 4(44), Vol.1. doi: 10.31435/rsglobal_ws/30042019/6467

Copyright: (C) 2019 G. I. Kordzakhia, L. D. Shengelia, G. A. Tvauri, M. Sh. Dzadzamia. This is an open-access article distributed under the terms of the Creative Commons Attribution License (CC BY). The use, distribution or reproduction in other forums is permitted, provided the original author(s) or licensor are credited and that the original publication in this journal is cited, in accordance with accepted academic practice. No use, distribution or reproduction is permitted which does not comply with these terms.

Introduction. The glaciers are an important climate-economic resource of the country as they contain a significant amount of freshwater. Glaciers make one of the major contributions to the formation of water regime and regional climatic conditions in the country.

Number of works [1] determine the glaciers rapid degradation worldwide due to the current climate change. The glacier melting causes the increase of the frequency and intensity of glacial and hydrological natural disasters [2], sea level increase and river run-off changes that affects the countries sustainable development.

The research of glaciers is related with a cluster of problems: 1 . Determination of the modern conditions of all glaciers of Georgia (glaciers area, length, the ablation and accumulation areas, glaciers maximal and minimal elevations etc.); 2. Research of glaciers degradation due to the current climate change: i. The reduction of glacier basins characteristic's (number of glaciers and area), ii. Small glaciers (area 0.1 to $0.5 \mathrm{~km}^{2}$ ) melting [3], iii. Large glaciers (area> $2 \mathrm{~km}^{2}$ ) retreat [4,5], iv. Definition of glaciers complete melting dates, v. Glacier water run off changes, etc.

The glacier basins characteristics changes, i.e. the changes of the number and size of glaciers are researched and some large glaciers possible complete melting dates are forecasted based on the large glaciers retreat trends under the current climate impact.

The Research Area and Methodology. The survey area is the Georgian part of the Great Caucasus Range territory. The glaciers in Georgia are located only in this area. 12 glaciated basins are in survey area, 6 of them are in western part of the Great Caucasus Range and 6 - in eastern part. 
Until 1970-ies, large volume of stationary and field glaciological monitoring works were carried out in the former Soviet Union. Based on that works the USSR glacier catalog (later catalog) was created. The glaciers from western and eastern Georgia are not considered independently and they are given in several parts of catalog [6].

After the collapse of the Soviet Union, stationary and field glaciological monitoring works were almost stopped in Georgia. Due to the current climate change the glaciers characteristics are significantly changed and their investigation is very important.

In recent years, episodic earth observations on the glaciers are renewed. In order to scientifically address the problem of glaciers melting under the current climate change impact the use of high-resolution satellite remote monitoring (SRM) is effective alternative to field glaciological monitoring works. This is provided by the facts that at present, it is impossible to make expensive field monitoring at needed level and capacity and only SRM is giving possibility to carry out the enhanced study of glaciated large areas with the required resolution and accuracy in conditions of the limited time and resources.

Based on the use of satellite remote sensing (SRS) it can be determined the glaciers most characteristics. This is achieved through the complex use of SRS images, historical data [6], glaciers schemes, the fieldwork materials [6] and expert's knowledge. The results are significantly depending on processing level of satellite data. The date of satellite information receiving and cloud cover are taken into consideration, but in some cases the images with high cloud coverage are representative. It is important to note that the corresponding methodology [3-5] includes the quality assessment and quality control $(\mathrm{QA} / \mathrm{QC})$ procedures that provides the successful outputs.

Glaciation Areas Changes in Conditions of Current Climate Change. The impact of the current climate change on Georgia's glaciated areas can be studied based on the comparative analysis of the glacier data obtained by use of SRM in 2012-2016 with the data of same glaciers from the catalog. The time difference between the catalog information and SRS data is about 50 years creating a prerequisite to assess glaciated areas changes.

Identification of some, especially the small glaciers on the satellite image can be carried out only based on catalog schemes. After identification of glaciers, number and area of glaciers in glaciated basins are defined. It appears that the area of certain glaciers identified by the SRS are greater than the related data from the catalog. This can mean that these glaciers area have increased on the background of global warming, or more likely the catalog data is inaccurate, having definite uncertainties. It is determined that 108 glaciers of western Georgia (26.4\% of total) and 7 glaciers of eastern Georgia (5.3\% of total) have inaccurate values of the area.

For the elimination of these uncertainties, the outlines and areas of the glaciers determined by the SRS are compared to corresponding ones plotted on the former USSR topographic maps. For all the glaciers having the above-mentioned uncertainties, it turns out that the areas specified by topographic mapping are greater than the areas of same glaciers determined by the SRS. Thus, the areas of glaciers define by topographic mapping are supposed to be true values confirming the degradation of these glaciers on the background of global warming.

Using this methodological approach, western (Table 1) and eastern (Table 2) Georgia's glaciation basins glaciers number and area are defined according to the catalog and current conditions (SRS).

For western Georgia the glaciers number in the glaciation basins were 409 and the occupied area was $456.1 \mathrm{~km}^{2}$ according to the catalog data. At present, the number of glaciers in western Georgia is 323, or $79 \%$ of initially existing one, while the occupied area is $331.2 \mathrm{~km}^{2}$, or $72.6 \%$ of the earlier existing one.

In eastern Georgia, the number of glaciers in the glaciation basins were 132 and the occupied area was $86.9 \mathrm{~km}^{2}$ according to the catalog data. At present, the number of glaciers in eastern Georgia is 60 , or $45.5 \%$ of initially existing one, while the occupied area is $45.8 \mathrm{~km}^{2}$, or $52.7 \%$ of the earlier existing one.

Table 1. Distribution of the western Georgia's glaciers according to the glaciation basins

\begin{tabular}{|c|l|c|c|c|c|c|c|}
\hline \multirow{2}{*}{$№$} & \multirow{2}{*}{ Glaciation basins } & \multicolumn{3}{|c|}{ Glaciers number } & \multicolumn{3}{c|}{ Glaciers area $\left(\mathrm{km}^{2}\right)$} \\
\cline { 3 - 8 } & & Catalog & SRS & $\Delta$ & Catalog & SRS & $\Delta$ \\
\hline 1 & Bzibi & 13 & 9 & 4 & 7.1 & 3.2 & 3.9 \\
\hline 2 & Kelasuri & 3 & 1 & 2 & 1.5 & 0.7 & 0.8 \\
\hline 3 & Kodori & 120 & 91 & 29 & 68.5 & 39 & 29.5 \\
\hline 4 & Enguri & 194 & 153 & 41 & 305.2 & 236.4 & 68.8 \\
\hline 5 & Khobistskali & 3 & 1 & 2 & 0.4 & 0.1 & 0.3 \\
\hline 6 & Rioni & 76 & 68 & 8 & 73.4 & 51.8 & 21.6 \\
\hline \multicolumn{2}{|c|}{ Total } & Total & 409 & 323 & 86 & 456.1 & 331.2 \\
\hline
\end{tabular}


Table 2. Distribution eastern Georgia's glaciers according to glaciation basins

\begin{tabular}{|c|l|c|c|c|c|c|c|}
\hline \multirow{2}{*}{ № } & \multirow{2}{*}{ Glaciation basins } & \multicolumn{3}{|c|}{ Glaciers number } & \multicolumn{3}{c|}{ Glaciers area $\left(\mathrm{km}^{2}\right)$} \\
\cline { 3 - 8 } & & Catalog & SRS & $\Delta$ & Catalog & SRS & $\Delta$ \\
\hline 1 & Liakhvi & 22 & 4 & 18 & 6.6 & 1.6 & 5 \\
\hline 2 & Aragvi & 5 & 1 & 4 & 1.6 & 0.3 & 1.3 \\
\hline 3 & Tergi & 68 & 35 & 33 & 67.5 & 39.5 & 28 \\
\hline 4 & Assa & 3 & 3 & 0 & 1.4 & 1 & 0.4 \\
\hline 5 & Arguni & 6 & 1 & 5 & 1.0 & 0.1 & 0.9 \\
\hline 6 & Pirikita Alazani & 28 & 16 & 12 & 8.8 & 3.3 & 5.5 \\
\hline \multicolumn{2}{r|}{ Total } & 132 & 60 & 72 & 86.9 & 45.8 & 41.1 \\
\hline
\end{tabular}

Thus, the area of the glaciation in western Georgia decreased by $27.4 \%$, the glacier's number $-21 \%$, while the glaciation area in East Georgia decreased by $47.3 \%$ and the glaciers number - by $54.5 \%$.

Totally, in Georgia the number of the glaciers was 541 and the occupied area was $443.0 \mathrm{~km}^{2}$ according to catalog. At present, the number of glaciers in Georgia is 383 or $70.8 \%$ of initially existing one, while the occupied area is $377.0 \mathrm{~km}^{2}$, or $85.1 \%$ of earlier existing one.

Thus, the area of the glaciation in Georgia decreased by $29.2 \%$, the glacier's amount $-14.9 \%$.

Large Glaciers Complete Melting. Impact of current climate change have significant negative impact on the glaciers and causes their rapid degradation. Some large glaciers full melting dates determination would be carried out according to one of the basic scenarios of current climate change, namely the business as usual (BaU). The dynamics of large glaciers retreat is determined based on the identification of the glacier tongue end locations. For the simplicity, those glaciers are chosen, which tongue is not covered by debris.

Methodology for determination of the glacier tongue retreat speed for large glaciers is given in [4]. For this purpose, Landsat sensors data is use.

Fig. 1 shows a schematic picture of Gergeti (a), Boko (b) Adishi (c) and Qvishi (d) glaciers retreat based on the SRM on the background images from 15. 08 and 07.09. 2015 and 09.09 and 24.08. 2016 correspondingly.

In different years, the glacier tongue locations are shown in different colors contours. The retreat locations and lengths for all these glaciers are calculated by white color zigzag lines, which cross the glaciers contours.

As an example we will show Gergeti glaciers mean retreat rates calculations and retreat tendencies analysis using glacier retreat characteristics (Table 3) received based on SRM data (Fig.1, a).

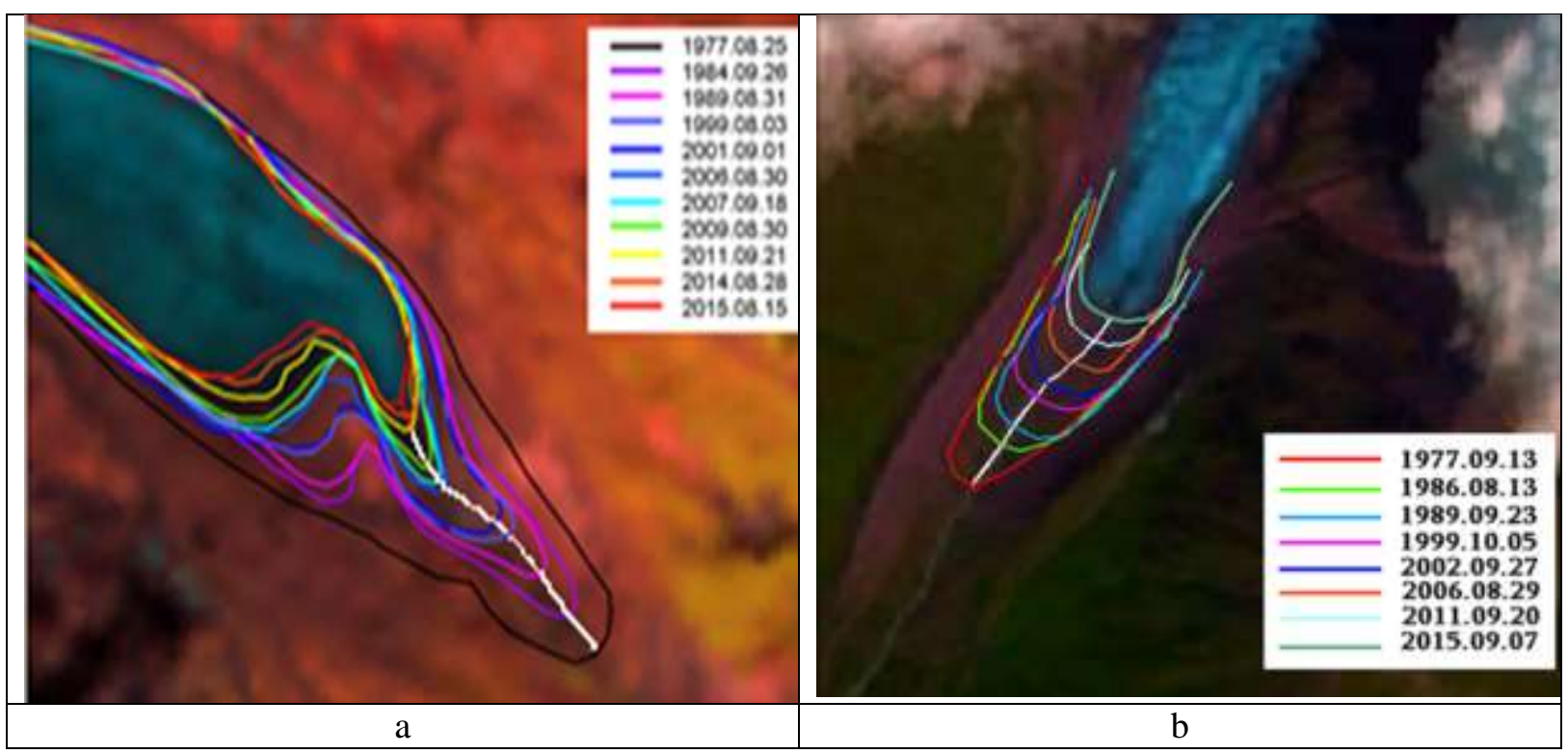




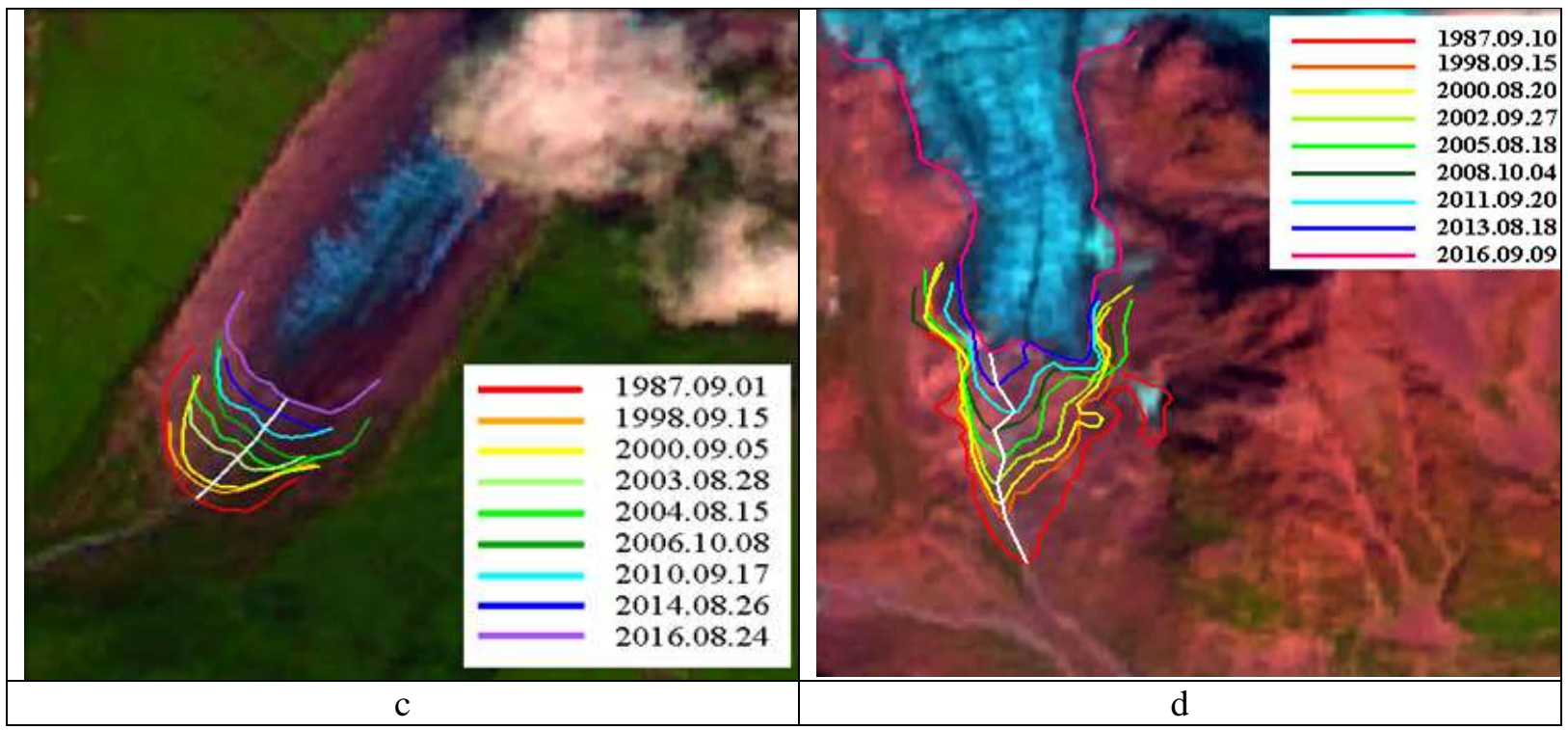

Fig. 1. The schematic picture of Gergeti (a), Boko (b), Adishi (c) and Qvishi (d) glaciers retreat images

The outputs of corresponding analysis shows that Gergeti Glacier's average retreat rates based on SRM data are: 1. Approximately $19.7 \mathrm{~m}$ per year for the whole observational period (1977-2015); 2. Approximately $15.1 \mathrm{~m}$ per year for the first 19 years period; and 3 . Approximately $26.7 \mathrm{~m}$ per year for the second 19 years period. The mean retreat rate in the second period significantly exceeds the tendencies determined for the first period as well as for the total observational period i.e. glacier retreat have a nonlinear character. The field observations glaciological monitoring data from the archives of the National Environmental Agency (NEA) are used to control the quality of determination of the glacier tongue end retreat speed obtained by the SRM. The outputs comparison shows their good coincidence.

Table 3. The Gergeti glacier tongue retreat locations and lengths according to dates.

\begin{tabular}{|c|c|c|c|c|c|}
\hline \multirow{2}{*}{ № } & \multirow{2}{*}{ Dates } & \multicolumn{2}{|c|}{ Coordinates } & \multirow{2}{*}{$\begin{array}{c}\text { The retreat related to the } \\
\text { previous location (m) }\end{array}$} & Total retreat (m) \\
\cline { 3 - 5 } & & Longitude & Latitude & & 0 \\
\hline 1 & $8 / 25 / 1977$ & $42.664006^{\circ}$ & $44.558418^{\circ}$ & 0 & 106 \\
\hline 2 & $9 / 26 / 1984$ & $42.664683^{\circ}$ & $44.557493^{\circ}$ & 106 & 217 \\
\hline 3 & $8 / 31 / 1989$ & $42.665486^{\circ}$ & $44.556670^{\circ}$ & 111 & 339 \\
\hline 4 & $8 / 3 / 1999$ & $42.666306^{\circ}$ & $44.555701^{\circ}$ & 122 & 379.6 \\
\hline 5 & $9 / 1 / 2001$ & $42.666503^{\circ}$ & $44.555308^{\circ}$ & 40.6 & 531.6 \\
\hline 6 & $8 / 30 / 2006$ & $42.667224^{\circ}$ & $44.553724^{\circ}$ & 152 & 557 \\
\hline 7 & $9 / 18 / 2007$ & $42.667407^{\circ}$ & $44.553513^{\circ}$ & 25.4 & 595.2 \\
\hline 8 & $8 / 30 / 2009$ & $42.667635^{\circ}$ & $44.553219^{\circ}$ & 38.2 & 690.1 \\
\hline 9 & $9 / 21 / 2011$ & $42.668386^{\circ}$ & $44.552674^{\circ}$ & 94.9 & 721.8 \\
\hline 10 & $8 / 28 / 2014$ & $42.668662^{\circ}$ & $44.552612^{\circ}$ & 31.7 & 756.2 \\
\hline 11 & $8 / 15 / 2015$ & $42.668917^{\circ}$ & $44.552400^{\circ}$ & 34.4 & 0.4 \\
\hline
\end{tabular}

Based on the received data, the further researches show that the retreat of the Gergeti glacier end can be approximated with the great precision by the parabola curve $y=0.2 t^{2}+10.2 t / 1 /$ (see Fig.2, a). The similar calculations for the glaciers Boko, Adishi and Qvishi (see Fig.2, b, c, d) give the equations correspondingly: $y=0.1 \mathrm{t}^{2}+13.7 \mathrm{t} / 2 /, \mathrm{y}=0.2 \mathrm{t}^{2}+8.4 \mathrm{t} / 3 /, \mathrm{y}=0.5 \mathrm{t}^{2}+8.0 \mathrm{t} / 4 /$.

For prediction of the Gergeti glacier complete melting dates business as usual (BaU) scenario of climate change is used. In this case calculations show that Gergeti glacier complete melting date is (BaU) 2140.

The same calculations for other glaciers being considered give following complete melting dates: i. Boko glacier in 2175, ii. Adishi glacier in 2146, iii Qvishi glacier in 2094. 
Conclusions. Based on the fulfilled research the following can be concluded:

1. The comparison of glaciers outlines created by use of SRS with the ones in the topographic maps of 1960-1970 of the last century, it can be inferred that all glaciation basins areas and numbers decreased in the last 50 years;

2. Analysis carried out for glaciation areas show that the reduction of glaciation areas and numbers is more intensive in eastern Georgia than in west Georgia;

3. The latter can be explained by the difference in climate between eastern and western parts of Georgia, namely, the eastern Georgia climate is continental, whereas the climate of western part of the country is a sea-wet and therefore, it is considerably humid;

4. Some large glaciers complete melting dates are calculated based on glacier end retreat and climate change $\mathrm{BaU}$ scenario. It is shown that even in conditions of worst scenario (BaU) of current climate change the complete melting of viewed large glaciers is not expected within this century.

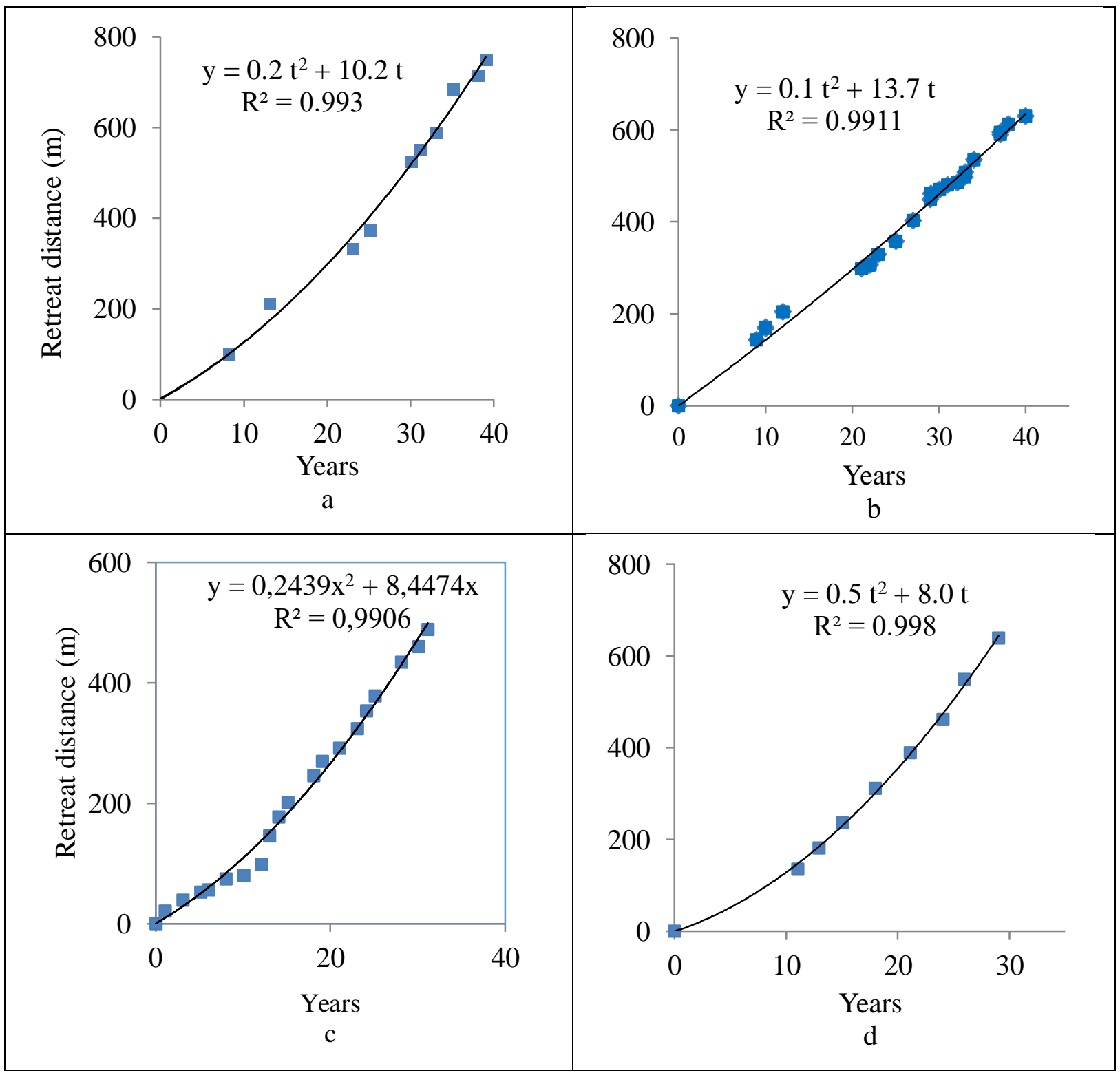

Fig.2. Gergeti (a), Boko (b) Adishi (c) and Qvishi (d) glacier retreat graph based on SRM data 


\section{REFERENCES}

1. Bates, B.C., Z.W. Kundzewicz, S.Wu and J.P. Palutikof, Eds., 2008: Climate Change and Water. Technical Paper of the Intergovernmental Panel on Climate Change. IPCC Secretariat, Geneva, 210 pp.

2. G. Kordzakhia, L. Shengelia, G. Tvauri, M. Dzadzamia. Research of Devdoraki Glacier Based on Satellite Remote Sensing Data and Devdoraki Glacier Falls in Historical Context, American Journal of Environmental Protection, Volume 4, Issue 3-1, 2015, pp. 14-21.

3. L.D. Shengelia, G.I. Kordzakhiya, G.A. Tvauri, M.Sh. Dzadzamiya. Results of the Research of Small Glaciers of Georgia Against the Background of the Change of the Modern Climate. „Geography: development of science and education", Collective monograph on materials of the annual International scientific and practical conference LXXI Gertsenovsky readings, St. Petersburg, RSPU of A.I. Herzen, on April 18-21, 2018 St. Petersburg: RSPU of name A.I. Herzen pubishing house, Vol. I, 2018, pp. 206-212 (in Russian).

4. G. Kordzakhia, L. Shengelia, G. Tvauri, V. Tsomaia, M. Dzadzamia. Satellite remote sensing outputs of the certain glaciers in the territory of East Georgia, The Egyptian Journal of Remote Sensing and Space Sciences - Elsevier, Volume 18, Issue 1, 2015, pp. S1-S7.

5. G. Kordzakhia, L. Shengelia, G. Tvauri, M. Dzadzamia. Impact of Modern Climate Change on Glaciers in East Georgia, Bulletin of the Georgian National Academy of Sciences, Vol. 10, №4 (2016), pp. 56-63.

6. Katalog lednikov SSSR. V. 8, Part. 11 (1977), Part 12 (1977); V. 9, Edition 1, Parts 2 - 6 (1975), Edition 3, Part. 1 (1975), L: Gidrometeoizdat (in Russian). 